\title{
FSH-FSHR3-stem cells in ovary surface epithelium: basis for adult ovarian biology, failure, aging, and cancer
}

\author{
Deepa Bhartiya and Jarnail Singh \\ Stem Cell Biology Department, National Institute for Research in Reproductive Health (ICMR), \\ Mumbai 400 012, India \\ Correspondence should be addressed to D Bhartiya; Email: deepa.bhartiya@yahoo.in
}

\begin{abstract}
Despite extensive research, genetic basis of premature ovarian failure (POF) and ovarian cancer still remains elusive. It is indeed paradoxical that scientists searched for mutations in FSH receptor (FSHR) expressed on granulosa cells, whereas more than $90 \%$ of cancers arise in ovary surface epithelium (OSE). Two distinct populations of stem cells including very small embryonic-like stem cells (VSELs) and ovarian stem cells (OSCs) exist in OSE, are responsible for neo-oogenesis and primordial follicle assembly in adult life, and are modulated by FSH via its alternatively spliced receptor variant FSHR3 (growth factor type 1 receptor acting via calcium signaling and the ERK/MAPK pathway). Any defect in FSH-FSHR3-stem cell interaction in OSE may affect folliculogenesis and thus result in POF. Ovarian aging is associated with a compromised microenvironment that does not support stem cell differentiation into oocytes and further folliculogenesis. FSH exerts a mitogenic effect on OSE and elevated FSH levels associated with advanced age may provide a continuous trigger for stem cells to proliferate resulting in cancer, thus supporting gonadotropin theory for ovarian cancer. Present review is an attempt to put adult ovarian biology, POF, aging, and cancer in the perspective of FSH-FSHR3-stem cell network that functions in OSE. This hypothesis is further supported by the recent understanding that: $i$ ) cancer is a stem cell disease and OSE is the niche for ovarian cancer stem cells; ii) ovarian OCT4-positive stem cells are regulated by FSH; and iii) OCT4 along with LIN28 and BMP4 are highly expressed in ovarian cancers.
\end{abstract}

Reproduction (2015) 149 R35-R48

\section{Introduction}

Gonadotropin hormones including follicle-stimulating hormone (FSH), luteinizing hormone ( $\mathrm{LH})$, and human chorionic gonadotropin (hCG) hormone are the central players of reproduction. A recent review (MertensWalker et al. 2012) has elegantly discussed the available literature suggesting that FSH in particular may be the main hormone responsible for ovarian cancers. High levels of $\mathrm{FSH}$ and $\mathrm{FSH}$ receptor (FSHR) expression in epithelial ovarian cancers (EOCs) are associated with a poor prognosis. FSH affects various aspects of ovarian cancer metastasis, such as it suppresses apoptosis, supports tumor growth by inducing increased expression of VEGFA (VEGF), facilitates blood vessel growth, and may alter certain oncogenic pathways that facilitate proliferative and invasive phenotype. Indeed, studies using nanoparticles conjugated to the $\beta$ subunit of FSH showed a lot of promise both in vitro and in vivo to increase the specificity and delivery of chemotherapeutic drugs (Zhang et al. 2009).

Hypothesis of 'incessant ovulation' being responsible for ovarian cancers was proposed more than 40 years ago (Fathalla 1971). This hypothesis indicates that ovarian cancer in women may occur due to frequent ovulation that causes repeated wounding and postovulation repair. This may result in accumulation of mutations in the epithelial cells and ultimately the formation of tumors. The other hypothesis termed 'gonadotropin theory' of cancer initiation (Stadel 1975) is supported by several circumstantial evidences including: i) increased incidence of ovarian cancers with advanced age when gonadotropin levels are elevated; ii) high FSH levels in ovarian cyst and peritoneal fluid; iii) protective effect of breast feeding and multi-parity that help suppress gonadotropin levels; and iv) increased risk of developing ovarian cancer in women with polycystic ovarian syndrome (PCOS) and those undergoing hyper-stimulation of ovaries with $\mathrm{FSH}$. But the gonadotropin hypothesis for development of ovarian cancers is still not well accepted. Studies carried out on genetically modified mice support the gonadotropin hypothesis. Sterile, germ-cell-deficient homozygous Wv mice having $<1 \%$ of normal number of oocytes at birth develop epithelial morphological changes including surface invaginations, inclusion cysts, and tumors associated with elevated gonadotropin levels similar to aged women (Murphy \& Beamer 1973). Interestingly, 
when the FSH levels in these mice were suppressed by Gonadotropin-releasing hormone agonist (Zoladex, $3.6 \mathrm{mg}$ slow-release goserelin depot injection every 28 days from the age of 7 days up to 245 days), no tumor developed (Blaakaer et al. 1995). Furthermore, these mice being sterile never ovulate and thus the concept of incessant ovulation does not explain the origin of ovarian cancer in these mice. Similarly, Chen et al. (2007) questioned the very basis for incessant ovulation to result in ovarian cancer as more than $90 \%$ of FORKO mice develop ovarian epithelial tumors by 12 months of age, which are otherwise sterile and never ovulate (Danilovich et al. 2001). Smith \& Xu (2008) have postulated that depletion of follicles and germ cells might underlie the etiology of ovarian cancers.

One needs to remember that FSH levels are increased in all aged, menopausal women but incidence of ovarian cancers is not very high. Thus, more than FSH, FSHRs may have a more crucial role in ovarian cancers. Besides ovarian cancers, elevated levels of FSH are also associated with premature ovarian failure (POF), resistant ovarian syndrome (ROS), and PCOS, and intense efforts have been undertaken to detect naturally occurring mutations in FSHR associated with these clinical conditions. Natural mutations detected in FSHR are relatively low compared with $\mathrm{LH}$ and thyroid-stimulating hormone $(\mathrm{TSH})$ receptors (Themmen \& Huhtaniemi 2000, Meduri et al. 2003, Themmen 2005, Huhtaniemi \& Themmen 2005). Mutations in FSHR appear to be a very rare cause of PCOS, POF, and primary to early secondary amenorrhea combined with arrested follicular maturation and anovulatory infertility. As shown in Table 1, mutations reported in exons 7 and 10 are always associated with primordial follicles (PFs) up to pre-antral stage. A large number of studies have been undertaken to search for mutations in FSHR in women having POF or ROS with negative results in New Zealand (Woad et al. 2013), India (Achrekar et al. 2010), Argentina (Sundblad et al. 2004), Japan (Takakura et al. 2001), Mexico (de la Chesnaye et al. 2001), the UK (Conway et al. 1999), and Brazil (Vilodre et al. 2008). First, reported Finnish mutation in FSHR by Aittomaki et al. (1995) was not found in 35 American women with ovarian failure (Layman et al. 1998) and was found in only one woman out of a total of 2840 women screened from Switzerland, Denmark, and Singapore (Jiang et al. 1998). Similarly, Bas et al. (2009) did not find any activating mutations in exon 10 of FSHR in four children with granulosa cell tumors. Besides FSHR, other sites have also been searched to find associations such as LHCGR/LH receptor (LHR), CYP17, inhibin, CYP19, NR5A1, and several other autosomal genes that result in non-syndromic POF such

Table 1 Mutations in FSHR and associated status of ovarian follicles (Siegel et al. 2013).

\begin{tabular}{|c|c|c|}
\hline References & $\begin{array}{l}\text { Exons where mutation } \\
\text { is detected }\end{array}$ & Effects on ovary \\
\hline Aittomaki et al. (1995) & 7 & $\begin{array}{l}\text { First, reported mutation in the Finnish population in women with primary amenorrhea. } \\
\text { They were }<20 \text { years of age, had elevated gonadotropin levels and normal karyotype. } \\
\text { Ultrasound of ovaries showed presence of follicles of varying sizes. On histological } \\
\text { evaluation, only primordial follicles were observed in some patients, but in others, } \\
\text { pre-antral or antral follicles were identified. In one patient, even a mature follicle was } \\
\text { identified. Corpora lutea were not reported indicating the failure of ovulation }\end{array}$ \\
\hline Beau et al. (1998) & 6 and 10 & $\begin{array}{l}\text { An Armenian woman with secondary amenorrhea and hypergonadotropic hypogonadism, } \\
\text { elevated gonadotropin levels, and normal karyotype. On transvaginal ultrasound, the } \\
\text { ovaries were normal in size and contained numerous, small (3-5 mm in diameter) antral } \\
\text { follicles. Impaired cAMP production. FSHR function not abolished completely, } \\
\text { FSH triggered cAMP response }(24+4 \%) \text { and FSH stimulation resulted in an increase in } \\
\text { the size of follicles from } 5 \text { to } 8.3 \mathrm{~mm}\end{array}$ \\
\hline Touraine et al. (1999) & 3 and 10 & $\begin{array}{l}\text { A } 19 \text {-year-old female with primary amenorrhea and elevated FSH levels. Ovary had many } \\
\text { follicles up to } 3 \mathrm{~mm} \text { in size. No binding with FSH was observed. No change in follicular size } \\
\text { after FSH stimulation, primordial, primary, secondary follicles and three antral follicles were } \\
\text { observed }\end{array}$ \\
\hline Doherty et al. (2002) & 10 & $\begin{array}{l}\text { A young female with primary amenorrhea. Hypergonadotropic ovarian failure was found to be } \\
\text { a compound heterozygote for two inactivating FSHR mutations: previously identified } \\
\text { Finnish founder mutation } 566 \mathrm{C} \rightarrow \mathrm{T} \text { novel } 1255 \mathrm{G} \rightarrow \text { A mutation in the other allele. These } \\
\text { mutations, resulting in Ala } 189 \mathrm{Val} \text { and Ala419Thr substitutions. Located in extracellular and } \\
\text { transmembrane domain. The patient had primary amenorrhea and normal female } \\
\text { secondary sexual characteristics. Small ovaries. No histological study of the ovaries } \\
\text { performed }\end{array}$ \\
\hline Allen et al. (2003) & 10 & $\begin{array}{l}\text { The patient presented with primary amenorrhea at } 17 \text { years of age Streak ovaries MRI } \\
\text { confirmed the presence of follicles }\end{array}$ \\
\hline Meduri et al. (2003) & 10 & $\begin{array}{l}\text { Normal-sized ovaries in women with high serum levels of FSH. Secondary or primary } \\
\text { amenorrhea with normal puberty. Ovaries showed a normal follicular development up to } \\
\text { the small antral stage and a disruption at further stages. Primordial and intermediary follicles } \\
\text { (few primary follicles) were observed }\end{array}$ \\
\hline Kuechler et al. (2010) & $\begin{array}{l}\text { Minimum deletion in } \\
\text { exons } 9 \text { and } 10 \text { and } \\
\text { maximum deletion in } \\
\text { exons } 7-10\end{array}$ & $\begin{array}{l}\text { A 17-year-old female with primary amenorrhea, hypergonadotropic hypogonadism, and } \\
\text { disturbed folliculogenesis. Many primordial follicles, but no secondary or tertiary follicles }\end{array}$ \\
\hline
\end{tabular}


as FOXL2, NOBOX, LHX8, FOX10A, FOX03A, FIGLA, POU5F1, NANOS3, RASGRP3, KIT, GDF9, BMPs, TGFB1 (TGF $\beta$ ), etc., but with no significant correlation (reviewed by Prof. Simpson 2008, Simpson during ASRM Meeting 2013). Genome-wide studies have recently revealed $8 \mathrm{q} 22.3$ as a possible regulatory region (Qin et al. 2012), which is not related to the FSHR gene located on chromosome 2.

Existing paradigm in ovarian biology suggests that FSHR are expressed on the granulosa cells in ovaries and on the Sertoli cells in testes (Renner et al. 2013, Siegel et al. 2013). This implies that research efforts till date to search for a genetic basis of POF and cancer have remained focused on FSHR coupling to G protein to activate cAMP on granulosa cells although both ovarian cancer and POF do not involve granulosa cells. It is well known that majority of ovarian cancers arise from the ovary surface epithelium (OSE) and POF implies absent follicles rather than follicles with defective granulosa cells. Stem cells present in the OSE have recently been shown to be involved in neo-oogenesis and PF assembly in adult mouse ovary (Bhartiya et al. 2012). Thus, changes in the OSE appear to be more crucial rather than granulosa cells of growing follicles for POF and cancer. It is likely that the world-wide research efforts to search for mutations in FSHR responsible for POF and ovarian cancer have been off the track. This happened basically because of the ease of availability of granulosa cells for research compared with the OSE cells. We need to acknowledge the large body of the available literature (Table 2) at both protein and transcript levels suggesting the presence of FSHR on OSE in normal and cancerous states (Bose 2008), 20-fold higher in oocytes compared with granulosa cells (Meduri et al. 2002), in blood vessels of normal gonads (Vu Hai et al. 2004) as well associated with various metastatic tumors (Siraj et al. 2013; Radu et al. 2010).

Thus, the present review goes beyond the existing paradigm of FSH-FSHR action on granulosa cells in the field of ovarian biology and examines closely the alternately spliced FSHR isoforms (Sairam \& Babu 2007) and their action on OSE. These variants may be implicated in normal ovarian function and also any aberration in them may result in menopause and be responsible for pathologies such as POF and ovarian cancer. A compromised somatic niche, for the stem cells lodged in the OSE, with age may not be able to provide the crucial growth factors/cytokines and thus result in suppressed stem cell differentiation into oocytes leading to senescence/menopause as has been suggested previously (Niikura et al. 2009, Massasa et al. 2010). Cancer is considered to be a stem cell disease and $90 \%$ of ovarian cancers arise in OSE. Thus, FSH-FSHR biology with a stem cell perspective may explain POF (altered stem cell biology may lead to failure of postnatal oogenesis and PF assembly resulting in POF), ovarian aging resulting in senescence/menopause (suppressed differentiation of stem cells into oocytes), and cancer (uncontrolled proliferation of stem cells) and is the focus of the present review (Fig. 1).

\section{FSH and FSHR isoforms}

$\mathrm{FSH}$ is a pituitary glycoprotein hormone composed of $\alpha$ and $\beta$ subunits of which $\alpha$ subunit is common to $\mathrm{FSH}, \mathrm{LH}, \mathrm{hCG}$, and TSH, whereas the $\beta$ subunit confers hormone specificity. Only the mature FSH dimer binds to FSHR. Various mutations in FSH and its effect on fertility have been recently reviewed by Siegel et al. (2013).

Table 2 FSH receptor (FSHR) expression in ovary surface epithelium (OSE).

\begin{tabular}{|c|c|}
\hline References & Salient findings \\
\hline tal. (1996) & $\begin{array}{l}\text { Expression of FSHR was studied in human OSE and fallopian tube by RTPCR and in situ hybridization (ISH). ISH studies } \\
\text { demonstrated the strongest FSHR mRNA expression in Graafian follicles, uniform and moderate in primary follicles and } \\
\text { OSE, weak in thecal cells, and absent in corpus luteum and corpus albicans. Abundant expression in Fallopian tube } \\
\text { mucosal epithelium. FSHR expression results were further confirmed by RT-PCR and sequencing of the amplified products }\end{array}$ \\
\hline Davies et a & $\begin{array}{l}\text { Administration of gonadotropins to sexually mature mice induced proliferation of OSE concurrently with the process of } \\
\text { folliculogenesis }\end{array}$ \\
\hline 1) & $\begin{array}{l}\text { The study demonstrated the effect of FSH and LH on bovine ovaries/OSE and human ovarian cancer cell lines (OCC1and } \\
\text { SKOV3) using RTPCR, qRTPCR, and northern blot techniques. Northern blot analysis demonstrated expression of FSHR } \\
\text { transcripts of variable sizes (1-7 kb) among different cell types ((four in bovine granulosa cells }-7,3,2 \text {, and } 1.5 \mathrm{~kb}) \text {, two in } \\
\text { human OCC } 1-3 \text { and } 2 \mathrm{~kb} \text { and one in bovine OSE }-1 \mathrm{~kb} \text { and no transcript in SKOV } 3 \text { ) }\end{array}$ \\
\hline Medur & $\begin{array}{l}\text { Presence of FSHR (and not LHR) detected in oocytes (from primary through preovulatory stage) using high-affinity MAB. } \\
\text { FSHR mRNA (reverse transcribed by random hexamer and PCR for exons } 7 \text { and 10) of denuded human oocytes and } \\
\text { porcine oocytes revealed a } 20 \text {-fold higher level than granulosa cells }\end{array}$ \\
\hline Wan & $\begin{array}{l}\text { Quantitative expression of FSHR in different types of ovarian epithelial tumors (OETs) presumed precursor lesion and } \\
\text { peritoneal implants were studied. Variable expression levels (highest in OSE and contralateral ovaries with and without } \\
\text { OETs; lowest in antral follicles, SBTs, and peritoneal implants associated with SBTs, increasing parallel to proliferation } \\
\text { activity of OETs and decreasing level with advancing carcinoma grade) were observed }\end{array}$ \\
\hline & \\
\hline & ure \\
\hline 006) & $\begin{array}{l}\text { Both PMSG and hCG increased OSE proliferation that could occur before and also after ovulation. No signs of apoptosis } \\
\text { were evident in OSE post-ovulation in CD1 mice }\end{array}$ \\
\hline & PMSG treatment results in increased FSHR expression in adult mouse OSE \\
\hline & d on the stem cells and germ cell nests in sheep OSE smears and the surrounding epithelial cells are negative \\
\hline
\end{tabular}




\section{Interaction among VSELs, FSH, and FSHR3 in ovary surface epithelium}

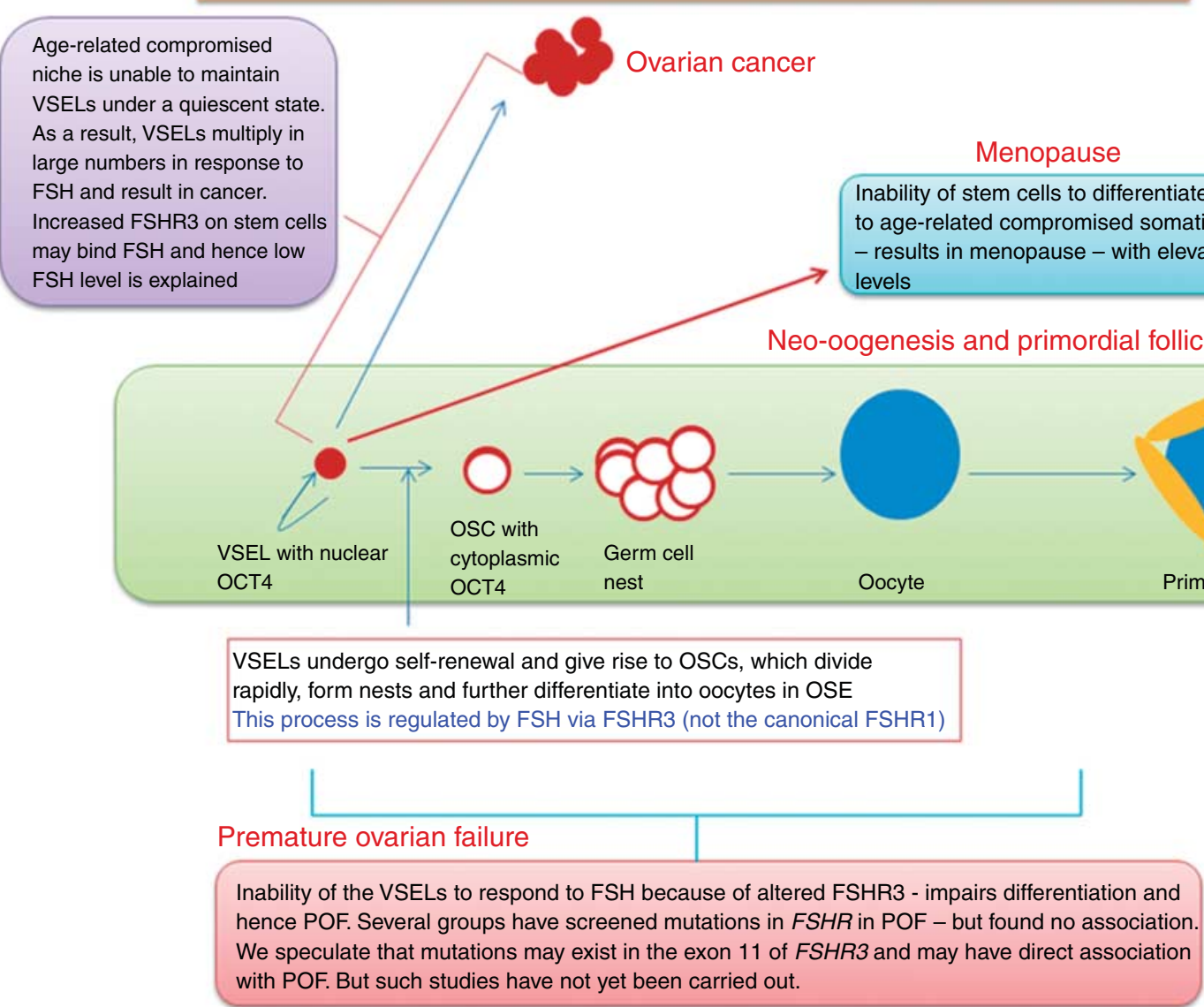

Figure 1 Schematic of the hypothesis put forth in the review. Two distinct populations of stem cells exist in OSE including the VSELs with nuclear OCT4 and the immediate descendant OSCs with cytoplasmic OCT4 (Parte et al. 2011, 2013, Bhartiya et al. 2012, 2013a,b). VSELs undergo selfrenewal and also give rise to the OSCs, which rapidly divide, form germ cell nests, and further differentiate into the oocytes. Oocytes get surrounded by granulosa cells, which possibly arise by epithelial-mesenchymal transition of the epithelial cells to assemble as a primordial follicle. This process of neo-oogenesis and PF assembly in adult ovary is regulated by FSH via FSHR3 (Patel et al. 2013). Any alteration in the FSH-FSHR-stem cell interaction will result in POF. Mutations in FSHR3 (specifically in exon 11) may result in POF and has not yet been studied. With advanced age, the somatic microenvironment (niche) is compromised and thus oocytes fail to differentiate resulting in senescence (menopause in women) and under certain conditions the stem cells may undergo uncontrolled proliferation resulting in cancer. OSE, ovary surface epithelium; VSELs, very small embryonic-like stem cells; OSCs, ovary stem cells, OCT4, transcription factor, nuclear OCT4 is crucial to maintain stem cells in the pluripotent state and, once cells initiate differentiation, OCT4 is expressed in cytoplasm and is eventually lost as cells differentiate further. FSH, follicle-stimulating hormone; FSHR3, alternatively spliced transcript of FSH receptor; POF, premature ovarian failure.

The FSHR gene is located on chromosome 2 and covers $54 \mathrm{~kb}$ in the humans and consists of ten exons and nine introns (Fig. 2). Sairam's group has made seminal contribution to the field of ovarian biology and has shown that FSHR exists as four alternatively spliced isoforms (R1, R2, R3, and R4) of which FSHR1 and FSHR3 have known biological functions and may help explain multiple actions of FSH including cellular growth, proliferation, differentiation, and steroidogenesis (Sairam \& Babu 2007, Table 3). Exons 1 through 9 encode the extracellular domain while the exon 10 encodes the C-terminal part of extracellular domain, the transmembrane domain, and intracellular domain. In addition, a putative intracellular exon 11 is also described. Canonical FSHR1 transcript comprises ten exons. FSHR2 transcript has an additional intracellular exon 11 on the C-terminal end joining with the truncated exon 10. FSHR3 consists of exons 1-8 spliced with exon 11, while exons 9 and 10 are spliced out. FSHR4 comprises only exons 1-4. FSHR4 is considered as a soluble receptor isoform, whereas FSHR2 is considered to be a dominant negative receptor isoform (Yarney et al. 1997a).

Various studies conducted by Sairam's group that led to the identification of FSHR isoforms in sheep and some functional characterization of putative Fshr3 isoform in mice are reviewed in Table 3. They also compared the putative peptide sequences of human FSHR3 and bovine FSHR3 with ovine FSHR3. FSHR1 is a G protein-coupled receptor that acts via the cAMP signaling pathway, whereas FSHR3 is a growth factor type I receptor that 


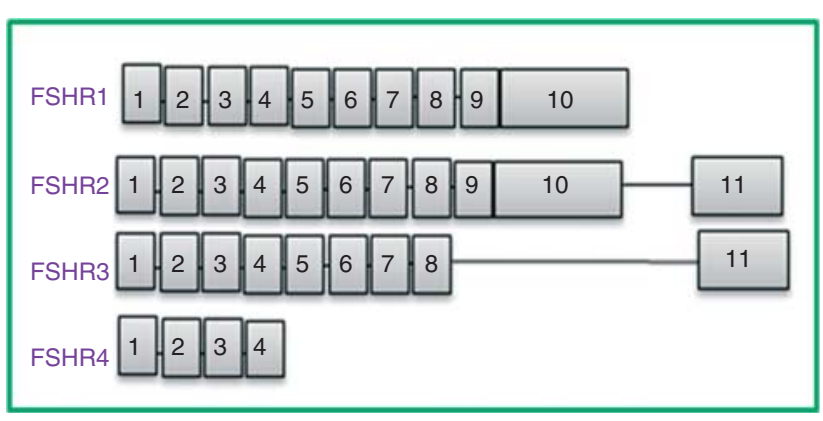

Figure 2 Exon structure of FSH receptor transcripts (splice variants) reported and characterized by Sairam's group (Table 2). The canonical FSHR1 comprises ten exons with the tenth exon being the largest. FSHR2 has a shorter exon 10 and an additional exon 11 at the $5^{\prime}$-end. FSHR3 comprises eight exons similar to canonical FSHR1 and additional exon 11 at the $5^{\prime}$-end. FSHR4 is the smallest comprising only four exons. Of the four transcripts, biological activity has been assigned to only FSHR1 and FSHR3. FSHR1 is a G protein-coupled receptor that acts via the CAMP pathway and is expressed on granulosa cells in ovary and Sertoli cells in testis. FSHR3 functions as a growth factor receptor and acts via calcium signaling and the MAPK/ERK pathway. It is expressed on ovary surface epithelial cells (Li et al. 2007) specifically on the stem cells present in the OSE (Patel et al. 2013) and also in follicles at different stages of development (Patel et al. 2013, Sullivan et al. 2013).

acts through calcium signaling and the MAPK/ERK pathway. FSHR1 is expressed on granulosa cells of growing follicles, whereas the smaller transcript (FSHR3) is predominant in ovarian surface epithelial cells and cancer cells when compared with granulosa cells (Li et al. 2007). Targeted disruption of FSHR in FORKO mice resulted in abnormal gametogenesis and hormonal imbalance (Dierich et al. 1998). As shown in Table 4, two studies clearly showed that FSH/pregnant mare serum gonadotropin (PMSG) treatment results in selective upregulation of Fshr3 compared with Fshr1 in mouse granulosa cells (Babu et al. 2001) and in sheep OSE cells (Patel et al. 2013). Sullivan et al. (2013) studied FSHR transcripts by qPCR in sheep follicles segregated based on the size into small, medium, and large. FSHR3 expression was higher than FSHR1 and FSHR2 in smalland medium-sized follicles irrespective of estrus. They conclude that alternately spliced $F S H R$ transcripts are involved in follicular dynamics and Fshr3 appears to be the most predominant form in sheep ovaries. But these are only a handful of studies, whereas the huge body of the literature on FSHR analysis in ovarian tissues and tumors fails to discriminate between FSHR splice variants as the antibodies/primers used are common for all the variants.

Exon 10 of canonical FSHR1 has remained the main target to search for mutations leading to POF and cancer. As mentioned earlier, till date, only few naturally occurring mutations have been reported for FSHR compared with almost 30 described for $L H R$ (Themmen \& Huhtaniemi 2000, Themmen 2005), although FSH is a key player controlling these processes. Siegel et al. (2013) provided an exhaustive review on the molecular basis of FSH action, including an update on mutations reported on FSHR. As shown in Table 1, mutations in the extracellular and transmembrane domains of protein region (corresponding to exons 6,9 , and 10 of the FSHR transcript) do not result in complete absence of follicles as follicles up to pre-antral stage were observed in these patients.

To conclude from this section, pleiotropic action of FSH on the ovary via alternatively spliced FSHR isoforms has not yet been well studied. Exon 11, which is specific to FSHR3, has not yet been screened for mutations in cases of POF and cancer. Although exon 11 of FSHR3 is largely intracellular, rather than FSH binding - it is plausible that cell signaling gets altered resulting in POF and cancer and is worth requiring further studies. But what is more exasperating is that gene and protein sequences for FSHR3 are not yet reported for mouse and human in the NCBI database. Only information available is about sheep FSHR3 in the UNIPROT database.

\section{OSE, stem cells, and FSH}

The ovary is surrounded by a whitish layer of OSE, which comprises simple squamous to cuboidal to low pseudostratified columnar epithelial cells. Embryologically OSE originates from the coelomic epithelium, which also gives rise to the epithelia lining the Fallopian tube, endometrium, cervix, and upper part of vagina. It has recently been advocated that besides OSE, epithelial neoplasms may also arise from the distal part of Fallopian tubes including fimbria (Karst et al. 2011) and later get deposited onto the OSE. This should not be of any concern as both OSE and oviductal epithelium have a common origin in coelomic epithelium (Auersperg 2013). OSE cells show a change in shape from cuboidal, flat to columnar and undergo a distinct cyclic change comprising the proliferative and quiescent phase. Gaytan et al. (2005) showed that two out of three of total proliferative activities in rat ovaries are associated with ovulation repair, whereas one out of three of proliferative activities occurs in areas distant from the site of ovulation. Singavarapu et al. (2010) carried out immunocytochemistry of whole mouse ovary and concluded that proliferation in OSE is more prominent during antral follicle growth rather than ovulatory wound repair. Wright et al. (2002) studied rhesus macaque OSE and found no signs of proliferation or apoptosis in the vicinity of follicle rupture. Thus, proliferation in OSE is an important event and does not occur only in response to post-ovulation repair. Recently, we have reported that treatment with the FSH analog PMSG results in extensive proliferation of OSE on day 2 with no associated sign of ovulation and we implicated it to neo-oogenesis from the stem cells lodged in the OSE (Bhartiya et al. 2012). Several groups have reported FSHR in normal OSE (Table 2) as well as in cancerous tissues. Ji et al. (2004) reported that FSHR mRNA was expressed in higher 
Table 3 Compilation of contributions made by Sairam's group on FSH receptor transcripts.

\begin{tabular}{|c|c|}
\hline References & Salient findings \\
\hline Yarney et al. (1993) & $\begin{array}{l}\text { Sheep testicular cDNA library constructed in pcDNA1 vector was screened using a } 1.6 \mathrm{~kb} \text { probe of rat LHR under low } \\
\text { stringency. A } 2085 \text { nucleotide open reading frame was found to encode a } 678 \text { aa FSHR protein. RNA blot showed two } \\
\text { major transcripts of } 2.6 \text { and } 6.7 \mathrm{~kb} \text { and a small } 1 \mathrm{~kb} \text { transcript in sheep testis. Transfection of HEK } 293 \text { cells with cloned } \\
\text { oFSH revealed cAMP accumulation. Thus, cloned receptor revealed properties similar to the WT FSHR }\end{array}$ \\
\hline Khan et al. (1993) & $\begin{array}{l}\text { Cloned and characterized two alternately spliced forms of sheep testicular FSHR mRNA. A smaller receptor cDNA of } \\
727 \mathrm{bp} \text { (from exon } 1 \text { to exon 4) codes for } 134 \text { amino acids and } 1.1 \mathrm{~kb} \text { cDNA clone (extending up to the 8th exon) codes } \\
\text { for a mature protein of } 259 \text { amino acids }\end{array}$ \\
\hline Yarney et al. (1997a) & $\begin{array}{l}\text { By PCR, northern analysis, cloning, and transfection studies on HEK } 293 \text { cells, a } 2.4 \mathrm{~kb} \text { transcript with absent cAMP- } \\
\text { induced functions was reported. It consisted of nucleotides - } 121 \text { to } 1924 \text { of FSHR and a novel 3' region comprising } \\
\text { nucleotides } 1925-2307 \text { that encoded a protein of } 670 \text { amino acids containing the entire extracellular domain and an } \\
\text { altered C-terminus }\end{array}$ \\
\hline Yarney et al. (1997b) & $\begin{array}{l}\text { Reported five distinct mRNA transcripts in male lambs of two different sheep genotypes. Of these, the } 1.1 \mathrm{~kb} \text { transcript } \\
\text { (151A1) comprising the first four exons of the FSHR gene was most abundant from } 11 \text { to } 22 \text { weeks of age coinciding } \\
\text { with increased steroidogenic and spermatogenic function }\end{array}$ \\
\hline Sairam et al. (1997) & $\begin{array}{l}\text { Studied the expression of a transcript (that encoded exons } 1-8 \text { and continued as a single transmembrane domain) in HEK } \\
293 \text { cells. This transcript was found to be expressed on the cell surface, showed high binding affinity with FSH, and no } \\
\text { competition with LH. They detected this transcript in both sheep ovary and testis. Results showed that the seven } \\
\text { transmembrane domains of the WT receptor are not crucial for cell surface expression of FSHR and for hormone binding }\end{array}$ \\
\hline $\begin{array}{l}\text { Sairam \& Subbarayan } \\
\text { (1997) }\end{array}$ & $\begin{array}{l}\text { This study was an attempt to clone the sheep FSHR gene. Obtained } 14 \text { clones and they reported exon } 11 \text { for the first time } \\
\text { beyond the exon } 10 \text {, which results in two different motifs including a dominant negative receptor and a growth factor } \\
\text { type } 1 \text {. The } 2.1 \mathrm{~kb} 5^{\prime} \text {-upstream region showed regulatory elements like ERE, CRE, an orphan receptor, and potential } \\
\text { germ cell-specific and methylation sites }\end{array}$ \\
\hline Babu et al. (1999) & $\begin{array}{l}\text { Documented for the first time that alternate splicing of G protein-coupled FSHR1 results in a transcript that comprises first } \\
\text { eight exons of FSHR1 spliced to another DNA segment resulting in a novel carboxyl terminus with a single } \\
\text { transmembrane domain. It was assigned to growth factor type } 1 \text { receptor family. It showed binding to FSH via calcium } \\
\text { signaling in both sheep ovary and testis }\end{array}$ \\
\hline Babu et al. (2001) & $\begin{array}{l}\text { Examined the expression of FSHR1 in adult mouse ovary and after PMSG treatment in immature mouse ovary - using } \\
\text { sheep-specific primers. FSHR3 was highly expressed in PMSG-treated ovary as confirmed by both RT-PCR and western } \\
\text { analysis }\end{array}$ \\
\hline Sairam \& Babu (2007) & $\begin{array}{l}\text { The work done on sheep and mouse gonadal tissues was reviewed. A single large gene of } \sim 250 \mathrm{~kb} \text { is a modular structure } \\
\text { whose pre-mRNA undergoes alternative splicing creating several subtypes (FSHR1-FSHR4). These isoforms have } \\
\text { identical N-terminus segments and different topographies are generated by differing carboxyl termini. Alignment of } \\
\text { FSHR2 and FSHR3 with human and bovine genome suggests similarity at both genome level in the organization of exon } \\
11 \text { and peptide sequence (almost } 64 \% \text { identity in the carboxyl terminus) }\end{array}$ \\
\hline
\end{tabular}

amounts in invasive tumors followed by low malignant tumors and least in normal OSE. Choi et al. (2004) reported that over-expression of FSHR in OSE cells led to an increase in EGFR, c-myc, and HER2/neu proteins and activated the ERK1/2 MAPK pathway. This suggests a pivotal role of FSHR expressed in the OSE during ovarian cancer development.

FSH treatment results in proliferation of OSE and it appears to be a direct effect via FSHR expressed on OSE cells. OSE proliferation after PMSG treatment has been reported earlier in mice (Davies et al. 1999, Burdette et al. 2006). Similar to PMSG-induced proliferation in OSE (Bhartiya et al. 2012), recombinant FSH treatment in mice ( $5 \mathrm{IU}$ for $48 \mathrm{~h}$ ) also results in marked changes in OSE (Fig. 3). Besides the observed effect on normal ovaries, FSH treatment is also reported to activate epithelial cell proliferation and oncogenesis in several human OSE immortalized normal, neoplastic (IOSE-29, IOSE-29E, and HOSE), and ovarian cancer cell lines (OVCAR-3 and OVCA) (Schiffenbauer et al. 1997, Zheng et al. 2000, Syed et al. 2001, Choi et al. 2004, Ji et al. 2004, Abd-Elaziz et al. 2005). Interestingly, this effect of FSH is associated with activation of MAPK/ERK rather than via the cAMP pathway (Choi et al. 2002, 2005). $\mathrm{Li}$ et al. (2007) showed that FSH acts on tumorigenic mouse ovary surface epithelium cell line ID8 via the growth factor-type receptor isoform (FSHR3) to bring about proliferation via calcium signaling and the ERK pathway - distinct from the canonical cAMP pathway associated with G protein-coupled FSHR1 isoform. Mertens-Walker et al. (2010) reported that gonadotropins activate the MAPK/ERK1/2 pathway in EOC cell lines (OV207 and OVCAR) responsible for increased proliferation and migration. Hilliard et al. (2013) have recently demonstrated that gonadotropins induce proliferation of normal mouse OSE and growth in soft agar and also suppress apoptosis.

To conclude this section, FSH exerts direct action through FSHR expressed on OSE cells through the MAPK/ERK pathway (suggesting involvement of FSHR3) in addition to its well-studied effect through FSHR expressed on granulosa cells via the cAMP pathway (via canonical FSHR1) in growing follicles. This action of FSH mediated through FSHR3 on the OSE may be implicated in ovarian biology as well as pathology.

\section{FSH-FSHR3-stem cell interaction is responsible for neo-oogenesis and PF assembly in adult mammalian ovary}

It has recently been shown that stem cells are localized in the adult mammalian OSE. The first paper challenging 
Table 4 Studies enumerating biological effects of FSHR transcripts

\begin{tabular}{|c|c|}
\hline Reference & Summary \\
\hline Yarney et al. (1997) & $\begin{array}{l}\text { This study was conducted to determine variations in the expression of alternate } \mathrm{FSH} \text { receptor mRNA transcripts in relation } \\
\text { to changes in FSH release, hormone binding activity and testicular function during pubertal development of ram lambs } \\
\text { from two genotypes of sheep } \\
\text { Five distinct species of mRNA transcripts of approximately } 1.1,1.5,2.0,2.5 \text { and } 6.5 \mathrm{~Kb} \text { were highly expressed from } 11 \text { to } \\
22 \text { weeks of age in sheep } \\
\text { Amongst these transcripts, the } 1.1 \mathrm{~Kb} \text { molecular species was the most abundant } \\
\text { The results indicated that contrasting changes in the production of specific alternatively spliced mRNA transcripts may } \\
\text { mediate changes in FSH receptor expression } \\
\text { The novel truncated transcript, which predictably encodes a soluble protein of either intra- or extracellular fate, could be } \\
\text { physiologically relevant }\end{array}$ \\
\hline Sairam et al. (1997) & $\begin{array}{l}\mathrm{I}^{125} \text { h-FSH binding studies were done in HEK } 293 \text { cells (both crude membrane preparations and surface of intact cells) } \\
\text { stably transfected with reconstructed HK18 cDNA clone and with full length ovine FSHR cDNA } \\
\text { Expression of altered FSHR transcript was studied in freshly collected adult sheep ovary and testicular tissues and stably } \\
\text { transfected HEK } 293 \text { cells } \\
\text { Expression of altered FSHR on cell surface was further confirmed by immunohistochemistry } \\
\text { Comparative hydropathy analysis of the HK18 and full length receptor revealed putative single transmembrane domain in } \\
\text { putative protein of altered FSHR which was further confirmed by hormone binding studies } \\
\text { Postulated a revised model for FSHR gene implicating the existence of an additional exonic sequence in FSHR gene }\end{array}$ \\
\hline $\begin{array}{l}\text { Babu et al. (1999) and } \\
\text { Toyuz et al. (2000) }\end{array}$ & $\begin{array}{l}\text { HEK } 293 \text { cells were transfected with FSHR isoforms R1, R2 and R3 } \\
\text { Only R3 induced rise in intracellular calcium in response to FSH treatment } \\
\text { LH or individual alpha or beta subunits of FSH showed no effect } \\
\text { Response was because of calcium influx and not due to intracellular mobilization of calcium } \\
\text { This was further confirmed since use of calcium channel blocker suppressed the response } \\
\text { FSH response via FSHR3 was seen in both ovary and testis }\end{array}$ \\
\hline Babu et al. (2000) & $\begin{array}{l}\text { Immortalized granulosa cells lacking endogenous FSHR were used for transfection with R1 and R3 } \\
\text { FSH associated proliferation was studied by BrdU/ triturated thymidine uptake } \\
\text { Transfected cells showed rapid and transient activation of ERK1 and ERK2 pathways } \\
\text { Pretreatment with MAPK/ERK and PKC inhibitors prior to FSH stimulation blocked ERK1 and ERK2 activation suggesting } \\
\text { that FSH acts via MAPK/ERK pathway to induce proliferation }\end{array}$ \\
\hline Babu et al. (2001) & $\begin{array}{l}\text { Investigated hormonal regulation of FSHR3 after PMSG treatment in immature mice } \\
\text { FSHR3 levels were significantly up-regulated by RTPCR compared to FSHR1 after PMSG } \\
\text { FSHR3 were localized in granulosa cells membrane }\end{array}$ \\
\hline Li et al. (2007) & $\begin{array}{l}\text { Tested the hypothesis whether FSH can stimulate ovarian cancer cell proliferation by acting on FSHR3, using the } \\
\text { tumorigenic mouse OSE cell line ID } 8 \\
\text { FSH enhanced ID } 8 \text { proliferation in a concentration-dependent fashion } \\
\text { Signalling pathway included cAMP-independent activation of ERK downstream of an SNX482 sensitive component likely } \\
\text { to be the Cav2.3 calcium channel } \\
\text { Northern analysis using probes specific for exons } 7 \text { and } 11 \text { of FSHR identified consistently only one } 1.9 \mathrm{~kb} \text { transcript } \\
\text { Immunoblot analysis confirmed expression of FSHR3 but not FSHR1 in ID8 } \\
\text { Data suggest that signalling promotes proliferation of ovarian cancer cells }\end{array}$ \\
\hline Patel et al. (2013) & $\begin{array}{l}\text { Studied sheep ovary surface epithelium cells in vitro } \\
\text { Stem cells of two different sizes (VSELs and OGSCs), few blood cells and epithelial cells were visualized in OSE smears } \\
\text { Stem cells expressed FSHR whereas the epithelial cells were negative } \\
\text { Upon FSH treatment, stem cells underwent rapid proliferation within } 15 \mathrm{~h} \text { in vitro as visualized by presence of germ cell } \\
\text { nests } \\
\text { In situ hybridization studies revealed selective activation of FSHR3 after FSH treatment } \\
\text { RNA was extracted from the cultured cells after } 3 \text { and } 15 \mathrm{~h} \text { and studied for FSHR1 and FSHR3 transcripts. Only FSHR3 } \\
\text { mRNA levels were up regulated at } 3 \mathrm{~h} \text { and return to basal level by } 15 \mathrm{~h} \\
\text { Results show that FSH via FSHR3 stimulates the ovarian stem cells to undergo proliferation, clonal expansion and further } \\
\text { differentiation }\end{array}$ \\
\hline Sullivan et al. (2013) & $\begin{array}{l}\text { Studied relative expression of FSHR1, FSHR2 and FSHR3 in sheep ovarian follicles from normal estrus cycle } \\
\text { Follicular fluid was aspirated from small }(2.0 \mathrm{~mm}) \text {, medium }(2.1-4.0 \mathrm{~mm}) \text {, large }(4.1-6.0 \mathrm{~mm}) \text { and pre-ovulatory (more } \\
\text { than } 6.1 \mathrm{~mm}) \text { follicles. Cells were pelleted and used for RNA extraction whereas the fluid was used for measuring } \\
\text { estradiol and progesterone (P) levels } \\
\text { P levels were maximum in pre-ovulatory follicles along with a slight increase in estradiol level } \\
\text { FSHR1 and FSHR3 transcripts were studied by qRT PCR } \\
\text { FSHR3 expression was maximum in medium sized follicles compared to FSHR1 and R2 } \\
\text { It was also more than LHR which were maximally expressed in pre-ovulatory follicles } \\
\text { Thus in addition to canonical G protein coupled receptor, FSHR3 is also involved in follicular dynamics }\end{array}$ \\
\hline
\end{tabular}

the concept of a fixed number of follicles in the adult ovary (Johnson et al. 2004) reported the presence of stem cells in the adult mouse OSE. Szotek et al. (2008) using $\mathrm{BrdU}$ incorporation and doxycycline inducible histone 2B-green fluorescent protein pulse-chase techniques identified a label-retaining stem/progenitor population in the coelomic epithelium of the adult mouse ovary. These cells were observed to exhibit quiescence with asymmetric label retention and functional response to estrous cycling in vivo by proliferation, showed in vitro 


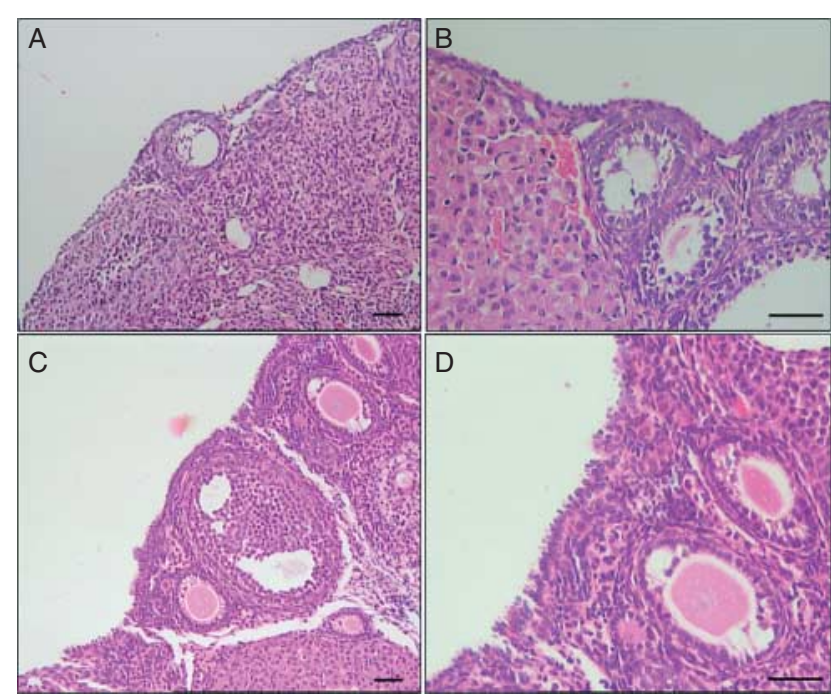

Figure 3 Effect of recombinant FSH treatment on mouse ovary surface epithelium. (A and B) H\&E stained sections of the adult mouse ovary. The presence of a non-discrete layer of ovary surface epithelium comprising small, flat to cuboidal epithelial cells is observed. (C and D) Effect of recombinant FSH treatment (5 IU, $48 \mathrm{~h}$ ) on OSE cells. The prominent, multilayered ovary surface epithelium comprising columnar epithelial cells is observed. These results are similar to the effect observed after PMSG treatment by our group (Bhartiya et al. 2012).Scale bar represents $20 \mu \mathrm{m}$.

colony formation, and were enriched as side population. Although the concept of stem cells in adult ovaries is still not well accepted - the conflict appears to be more technical (Bhartiya 2012, Bhartiya et al. 2013a, Woods et al. 2013) and hopefully will be resolved in due course. In addition to the seminal contributions made by Jonathan Tilly's group in the field, recently equating ovarian stem cells (OSCs) to spermatogonial stem cells (SSCs) in testis (Woods et al. 2013), and their protocols to isolate OSCs (Woods \& Tilly 2013), our group has reported an additional population of stem cells (VSELs) in both ovary and testis (Bhartiya et al. 2010, 2013b, Parte et al. 2011), in addition to the OSCs/OGSCs.

A gentle scraping of OSE from mouse, rabbit, sheep, monkey, and human ovaries shows the presence of two population of stem cells including nuclear OCT4positive very small embryonic-like stem cells (VSELs) and slightly bigger progenitors with cytoplasmic OCT4 (OGSCs/OSCs), which exist singly or as a cluster termed the germ cell nest (Bhartiya et al. 2013a,b, Parte et al. 2014). Similarly, Virant-Klun's et al. (2013) has reported that OSE harbors stem cells, which spontaneously differentiate into oocyte-like structures during in vitro culture. Our group also observed spontaneous differentiation of OSE cells into oocyte-like structures and that the epithelial cells undergo epithelial-mesenchymal transition to form granulosa-like cells that surround the developing germ cells resulting in follicle assembly (Parte et al. 2011). Further studies in marmosets and humans have revealed that ovarian cortical tissue slices, besides being a good source of PFs (for cancer patients to achieve biological parenthood), are also an excellent source of stem cells (Parte et al. 2013). We observed that FSH treatment results in increased proliferation of OSE and increased number of stem cells as reflected by increased expression of pluripotent transcripts (OCT4A and $N A N O G)$, even in a sample collected from a 60 -year-old woman. The stem cells from aged ovaries have the ability to differentiate into oocyte-like structures during in vitro culture (because the inhibitory factors in situ were overcome in vitro). Similarly, others have also described the presence of stem cells in post-menopausal women OSE, which differentiate into oocytes and parthenote embryos in culture (Virant-Klun \& Skutella 2010). Various events such as formation of germ cell nests, Balbiani body-like structures, and cytoplasmic streaming, which are extensively studied in fetal ovary, are recapitulated during in vitro oogenesis in adult OSE cultures along with characteristic expression of stem/ germ cell/oocyte markers (Parte et al. 2014).

VSELs are spherical cells with an intensely hematoxylinstained nucleus surrounded by a thin rim of cytoplasm and a high nucleo-cytoplasmic ratio. These stem cells are easily visualized in gently scraped OSE smears (Parte et al. 2011) and express various pluripotent markers including nuclear OCT4 and undergo clonal expansion in response to PMSG treatment (Bhartiya et al. 2012). Patel et al. (2013) have shown that sheep OSCs express FSHR whereas the epithelial cells are distinctly negative. In situ hybridization results further showed the presence of both FSHR1 and FSHR3 mRNAs in the stem cells; however, only FSHR3 showed active transcription after FSH treatment of OSE cells in vitro. Quantitative RT PCR studies on FSHR transcripts R1 and R3 showed a distinct upregulation of $F S H R 3$ within $3 \mathrm{~h}$ of FSH treatment and that levels return to basal levels by $15 \mathrm{~h}$. Thus, evidence is available to suggest that the stem cells lodged in the OSE respond to FSH via a growth factor-type receptor isoform FSHR3, which acts via the MAPK/calcium signaling pathway. This is a novel effect of FSH on OSCs recently deciphered by our group and the results are compiled in Table 5.

However, owing to their very small size (smaller than red blood cells), VSELs have remained obscure, controversial, and poorly studied till date (Abbott 2013, Ratajczak et al. 2014). Emerging literature suggests that VSELs do exist and similar to mouse bone marrow VSELs that survive total body irradiation (Ratajczak et al. 2011), we have observed that both adult mouse testicular (Anand et al. 2014) and ovarian VSELs survive chemotherapy (Fig. 4) because of their relatively quiescent state. The VSELs present in the chemo-ablated mouse OSE express nuclear OCT4 (Fig. 4) and also respond to FSH (K Sriraman, D Bhartiya, S Anand, and S Bhutda, unpublished observations). Similarly, Anand et al. (2014) have shown that mouse testicular VSELs survive 
Table 5 Emerging understanding of FSH modulation of adult mouse ovarian stem cells resulting in neo-oogenesis and primordial follicle assembly (Bhartiya et al. 2012).

\begin{tabular}{|c|c|}
\hline Our results & Inference \\
\hline $\begin{array}{l}\text { OSE proliferation was noted during the estrous state and also after } \\
\text { PMSG treatment associated with increased PCNA staining }\end{array}$ & $\begin{array}{l}\text { Similar to OSE proliferation observed during the normal estrous cycle; } \\
\text { PMSG (FSH analog) exerts direct proliferative action on OSE in } \\
\text { addition to the well-studied action on granulosa cells of growing } \\
\text { follicles }\end{array}$ \\
\hline Increased FSHR expression in OSE after PMSG treatment & PMSG action is mediated via FSH receptors that are expressed on OSE \\
\hline $\begin{array}{l}\text { Nuclear OCT4, a marker specific for pluripotent stem cells (VSELs) } \\
\text { present in the OSE is also observed in developing oocytes after } \\
\text { PMSG treatment }\end{array}$ & $\begin{array}{l}\text { Oocytes arise from nuclear OCT4-positive VSELs } \\
\text { VSELs self-renew, give rise to OGSCs that divide rapidly and give rise to } \\
\text { germ cell nests, undergo meiosis, and give rise to oocytes (with nuclear } \\
\text { OCT4) }\end{array}$ \\
\hline $\begin{array}{l}\text { Mouse VASA homologue (MVH) immunolocalization in germ cell } \\
\text { clusters and oocytes after PMSG treatment }\end{array}$ & $\begin{array}{l}\text { PMSG treatment results in increased germ cell proliferation, clonal } \\
\text { expansion with incomplete cytokinesis, and differentiation }\end{array}$ \\
\hline $\begin{array}{l}\text { SCP3 staining in oocytes at both protein and transcript levels after } \\
\text { PMSG treatment }\end{array}$ & $\begin{array}{l}\text { Ovarian stem cells differentiate into germ cells, which also undergo } \\
\text { meiosis during adult life }\end{array}$ \\
\hline $\begin{array}{l}\text { PMSG treatment results in increased transcripts of pluripotent } \\
\text { stem cells }(\text { Oct4A and Nanog), early primordial germ cell-specific } \\
\text { markers (Oct4, Stella, Fragilis), germ cell markers }(M v h) \text {, early } \\
\text { oocyte-specific markers (Nobox and Hoxa10), premeiotic marker } \\
\text { (Scp3), meiosis-specific homologous recombination-specific } \\
\text { marker (Dmc1), and PMSG action mediator (Fshr) }\end{array}$ & $\begin{array}{l}\text { Pluripotent VSELs undergo proliferation } \\
\text { Primordial germ cells persist in adult ovary as VSELs } \\
\text { Upon differentiation, germ cell markers are expressed } \\
\text { VSELs differentiate into oocytes and also undergo meiosis } \\
\text { Neo-oogenesis in adult ovary is mediated via FSH through FSHR } \\
\text { expressed on the stem cells in OSE }\end{array}$ \\
\hline
\end{tabular}

apatel et al. (2013) showed by studies on sheep OSE smears that FSHR are selectively expressed on the stem cells (epithelial cells remain negative).

chemotherapy and are able to restore spermatogenesis in chemo-ablated testis when a healthy niche is provided.

We have further studied the underlying mechanism of how these stem cells lodged in the OSE are regulated by $\mathrm{FSH}$ and are responsible for neo-oogenesis and PF assembly in adult ovary similar to the mechanism how SSCs are involved during spermatogenesis in testis (Bhartiya et al. 2012, Patel et al. 2013). Adult mouse OSE proliferation and PF assembly occur in a very subtle manner during the normal estrous cycle and the process gets augmented after PMSG treatment (Table 5). Certain degree of OSE proliferation was observed in the proestrous stage of the normal estrous cycle, which became prominent during the estrous state and at a higher magnification - cohorts of PF with cytoplasmic continuity were observed just below the OSE - resembling a 'nest'. Presence of cytoplasmic continuity among the developing PF suggests that they were newly formed rather than pre-existing follicles from birth because, as per current understanding, germ cell nest breakdown occurs just after birth (Xu \& Gridley 2013). Stimulation with recombinant $\mathrm{FSH}$ resulted in similar OSE proliferation on day 2 (Fig. 3). Concluding this section, it is indeed the stem cells in the OSE that express FSHR and respond to FSH via FSHR3 resulting in neo-oogenesis and PF assembly during adult life. Any defect in the stem cell biology in the OSE will possibly result in the failure of PF to assemble and this may give rise to a phenotype of absence of follicles characteristic of POF.

\section{FSH-FSHR3-stem cell interaction in OSE is implicated during POF, aging, and cancer}

POF is a heterogeneous disorder that occurs at the frequency of $<1 \%$ in women below 40 years of age.
Besides having a genetic basis and autoimmune etiology, POF may also be caused by surgical removal of ovaries or it occurs as a side effect of oncotherapy for various non-gynecological malignancies. Despite huge efforts, as discussed and elaborated above, genetic basis for POF is still not elucidated. We propose that mutations, specifically in intracellular exon 11 of FSHR3, could possibly result in impaired signaling (not binding to $\mathrm{FSH}$ ) that may result in suppressed stem cell function and, thus, primordial follicle assembly will not occur resulting in POF associated with elevated FSH levels (Fig. 1).

On similar lines, it has been suggested that the microenvironment (niche) supporting the stem cells gets compromised with age (not able to provide the required growth factors/cytokines) and stem cells are not able to differentiate into oocytes thus resulting in menopause (Tilly \& Telfer 2009, Massasa et al. 2010) with associated elevated FSH levels (Fig. 1). Nikura et al. (2009) demonstrated that the stem cells from aged ovary retain the differentiation potential and form oocytes when exposed to young ovarian environment. Similarly, it has been recently concluded that compromised somatic niche due to oncotherapy does not support testicular stem cell differentiation (Oatley \& Brinster 2012). Chakkalakal et al. (2012) also suggested that the niche gets compromised with age in muscles resulting in altered stem cell function. Bukovsky (2011) has reported that it is possibly a functional decline of immune system between 35 and 40 years of age that could also be responsible for termination of neo-oogenesis and follicular assembly and hence menopause. As mentioned earlier, stem cells isolated from adult OSE retain the ability to undergo spontaneous differentiation into oocyte-like structures in vitro (Virant-Klun \& Skutella 2010, Parte et al. 2011, 2014). Thus, despite elevated FSH levels, compromised 


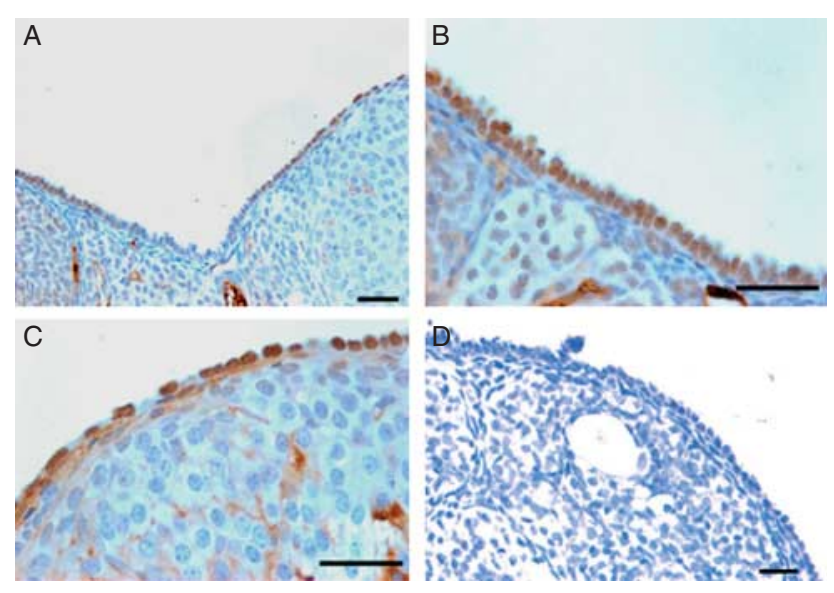

Figure 4 OCT4-positive stem cells in mouse ovary. (A) Lowmagnification view of a chemo-ablated $(10 \mathrm{mg} / \mathrm{kg}$ busulfan daily for 4 days and $100 \mathrm{mg} / \mathrm{kg}$ cyclophosphamide for first 2 days) mouse ovary with prominent OSE. A heterogeneous staining pattern with unstained epithelial cells interspersed with distinct nuclear Oct4-expressing stem cells is clearly evident. Mouse VSELs survive chemotherapy (Anand et al. 2014) as well as radiotherapy (Ratajczak et al. 2011) possibly because of their quiescent nature and increase in numbers but do not differentiate in the chemo-ablated gonad because the somatic niche is compromised. These stem cells are not easily evident in untreated mouse ovarian sections but are clearly observed in chemo-ablated ovary and respond to FSH (K Sriraman, D Bhartiya, S Anand, and $S$ Bhutda, unpublished observations). (B and C) Higher magnification showing the presence of nuclear to cytoplasmic OCT4 expression in stem cells located in the OSE. (D) Negative control. Scale bar represents $20 \mu \mathrm{m}$.

somatic microenvironment of the ovary results in menopause (Fig. 1).

Continuous stimulation of stem cells by elevated levels of circulatory FSH may also act as a trigger to stimulate their proliferation and, under certain yet not wellunderstood conditions, results in cancer. POF cases may not be prone to developing ovarian cancer - mainly because the underlying mechanisms are very different. POF may occur because of a mutation in FSHR whereas the FSH-FSHR-stem cell interaction and PF assembly were normal in women for some time before they develop cancer. Cancer patients may not necessarily show any mutation in FSHR - rather cancer has been proposed to be a stem cell disease and some change in the somatic microenvironment (niche) results in uncontrolled proliferation of otherwise quiescent VSELs resulting in cancer. Thus, it is not surprising that Schildkraut et al. (2001) found no correlation between age at menopause and ovarian cancer. POF cases (unlike cancer patients) are also likely to have associated elevated FSH levels. VSELs express FSHR and their increased numbers may result in excessive binding of FSH with FSHR and, hence, FSH levels are not always elevated in ovarian cancer patients. This could be a likely explanation for lowered FSH levels in ovarian cancer patients (Fig. 1), in addition to the role of neurotropins as suggested previously (Bose 2005).
The understanding of FSH-FSHR3-stem cells in OSE provides a plausible explanation as to: i) why more than $90 \%$ of ovarian cancers arise in the OSE; ii) why FSHR is expressed on the ovarian cancer cells; and iii) why there is an increased incidence of cancers with age, and thus supports the gonadotropin theory of ovarian cancer with a stem cell perspective.

The hypothesis that the stem cells under the effect of elevated FSH levels may result in ovarian cancer gets further credence from the current understanding that cancer is a stem cell disease. VSELs could be the embryonic remnants in adult organs including ovaries responsible for cancers in adult life (Ratajczak et al. 2010). Neonatal exposure to estrogen/endocrine disruptors is known to be associated with an increased risk of cancer in adult life and a recent study by our group has implicated altered VSEL biology to be the underlying cause for an increased risk of cancer (Bhartiya et al. 2013c). Nuclear OCT4 is a pluripotent stem cell marker expressed by VSELs lodged in OSE and is also reported to be over-expressed in ovarian cancer. Zhang et al. (2013) reported over-expression of OCT4 in ovarian carcinoma compared with benign cystadenomas and borderline tumors. OCT4 expression was significantly correlated with the histological grade as staining for OCT4 was increased in serous cystadenocarcinoma, when compared with clear cell carcinoma. FSH stimulation resulted in a significant increase in both nuclear and cytoplasmic OCT4 protein in a dose-dependent manner in both Hey and OVCAR3 cell lines. Ma et al. (2013) have implicated Lin28/OCT4/BMP4-mediated mechanism in ovarian tumor cell growth by further extending the earlier report by Peng et al. (2010) indicating co-expression of LIN28 and OCT4 in a subpopulation of cells in cancer cell lines and tumor tissue and expression intensity correlated with the tumor grade. They proposed that Lin28 and OCT4 may have important roles in the initiation and/or progression of EOCs. Samardzija et al. (2012) have discussed OCT4 and ovarian cancer and reported nuclear OCT4-positive cells to be present as a core of tumor spheroids. Thus, it is becoming increasingly apparent that normal ovarian nuclear OCT4-positive VSELs are also implicated in ovarian cancers. A paper published recently by Flesken-Nikitin et al. (2013) is also extremely relevant. This group by elegant lineage tracing studies concluded that OSE in the hilum region is the stem cell niche for ovarian cancer stem cells in the mouse ovary and also has the ability to regenerate the OSE.

\section{Conclusions}

We need to appreciate the novel action of FSH on the stem cells lodged in the OSE via FSHR3. The research focus should be on exon 11 of FSHR to search for mutations in cases of POF and cancer. For this, we need to first sequence FSHR3 in mouse and human and study 
FSHR3 biology by raising specific antibodies. This review opens up several new areas for research and also questions several existing paradigms in ovarian biology, including the following: i) initial follicle growth is FSH independent and ii) $\mathrm{FSH}$ exerts action on granulosa cells of follicles in ovary. By contrast, we have compiled the available literature suggesting that: i) stem cells are present in OSE and express FSHR; ii) neo-oogenesis and PF assembly occur in adult ovary in response to $\mathrm{FSH}$; and iii) FSH exerts its action via a novel transcript FSHR3. Any perturbation in the FSH-FSHR3stem cell network in OSE may possibly result in menopause and most probably be responsible for various pathologies such as POF and cancer.

On comparing POF in women with azoospermia in men, it is indeed intriguing that similar to POF, genetic basis for azoospermia is also not yet deciphered and no significant association is reported with the FSHR gene (or any other) and male infertility. VSELs exist in human (Bhartiya et al. 2010) and mouse (Anand et al. 2014) testis as in the ovaries and nuclear OCT4 is a specific and sensitive marker for testicular cancers (Jones et al. 2004). Studies are currently ongoing in our laboratory to study the effect of FSH on testicular stem cells before we implicate FSH-FSHR3-stem cell interaction in testicular biology and azoospermia as well.

\section{Key messages}

1. Stem cells, including VSELs (with nuclear OCT4) and their descendants OSCs (with cytoplasmic OCT4), are localized to the OSE and are regulated by $\mathrm{FSH}$ to undergo neo-oogenesis and PF assembly.

2. This novel action of FSH on the stem cells in the OSE is mediated via the alternately spliced FSHR transcript FSHR3. FSHR3 is an important and abundantly expressed transcript involved in follicular dynamics and is also highly expressed in ovarian cancer cells.

3. The FSHR3 transcript has not yet been searched for mutations in women with POF. FSHR3 has a unique exon 11, which needs to be sequenced and studied in details, as exons $1-8$, which are common with canonical FSHR1, have already been screened.

4. Compromised somatic microenvironment (niche) with age does not support normal stem cell proliferation, differentiation, neo-oogenesis, and PF assembly - thus resulting in age-related senescence/menopause.

5. Certain (yet not well understood) changes in the stem cell niche trigger uncontrolled proliferation of stem cells and thus cancer.

6. VSEL biology in the adult ovary needs to be acknowledged, FSHR3 needs to be sequenced in humans and mice, exon 11-specific antibodies need to be generated, and detailed studies need to be undertaken to better understand ovarian biology, POF, menopause, and also cancer. Deciphering the specific and distinct changes in the niche that result in menopause and cancer is challenging but will have huge relevance in the field of reproductive medicine.

\section{Declaration of interest}

The authors declare that there is no conflict of interest that could be perceived as prejudicing the impartiality of the review.

\section{Funding}

J Singh is grateful to the Indian Council of Medical research for his Post-Doctoral fellowship. The work toward this article is supported by the Indian Council of Medical Research, New Delhi, India. NIRRH manuscript accession number: REV/119/04-2014.

\section{Acknowledgements}

The significant contributions of Seema Parte, Hiren Patel, and Kalpana Sriraman at Stem Cell Biology Department, NIRRH, toward arriving at this hypothesis are acknowledged.

\section{References}

Abbott A 2013 Doubt cast over tiny stem cells. Nature 499 390. (doi:10. 1038/499390a)

Abd-Elaziz M, Moriya T, Akahira J, Suzuki T \& Sasano H 2005 StAR and progesterone producing enzymes ( $3 \beta$-hydroxysteroid dehydrogenase and cholesterol side-chain cleavage cytochromes P450) in human epithelial ovarian carcinoma: immunohistochemical and real-time PCR studies. Cancer Science 96 232-239. (doi:10.1111/j.1349-7006.2005.00040.x)

Achrekar SK, Modi DN, Meherji PK, Patel ZM \& Mahale SD 2010 Follicle stimulating hormone receptor gene variants in women with primary and secondary amenorrhea. Journal of Assisted Reproduction and Genetics 27 317-326. (doi:10.1007/s10815-010-9404-9)

Aittomaki K, Lucena JL, Pakarinen P, Sistonen P, Tapanainen J, Gromoll J, Kaskikari R, Sankila EM, Lehvaslaiho H, Engel AR et al. 1995 Mutation in the follicle-stimulating hormone receptor gene causes hereditary hyper gonadotropic ovarian failure. Cell 82 959-968. (doi:10.1016/00928674(95)90275-9)

Allen LA, Achermann JC, Pakarinen P, Kotlar TJ, Huhtaniemi IT, Jameson JL, Cheetham TD \& Ball SG 2003 A novel loss of function mutation in exon 10 of the FSH receptor gene causing hypergonadotrophic hypogonadism: clinical and molecular characteristics. Human Reproduction 18 251-256. (doi:10.1093/humrep/deg046)

Anand S, Bhartiya D, Sriraman K, Patel H \& Manjramkar DD 2014 Very small embryonic-like stem cells survive and can restore spermatogenesis after busulphan treatment in mouse testis. Journal of Stem Cell Research \& Therapy 4 7. (doi:10.4172/2157-7633.1000216)

Auersperg N 2013 The stem-cell profile of ovarian surface epithelium is reproduced in the oviductal fimbriae, with increased stem-cell marker density in distal parts of the fimbriae. International Journal of Gynecological Pathology 32 444-453. (doi:10.1097/PGP.0b013e3182800ad5)

Babu PS, Jiang L, Sairam AM, Touyz RM \& Sairam MR 1999 Structural features and expression of an alternatively spliced growth factor type I receptor for follitropin signaling in the developing ovary. Molecular Cell Biology Research Communications 2 21-27. (doi:10.1006/mcbr.1999. 0139)

Babu PS, Krishnamurthy H, Chedrese PJ \& Sairam MR 2000 Activation of extracellular-regulated kinase pathways in ovarian granulosa cells by the novel growth factor type 1 follicle-stimulating hormone receptor. Role in hormone signaling and cell proliferation. Journal of Biological Chemistry 275 27615-27626. (doi:10.1074/jbc.M003206200) 
Babu PS, Danilovich N \& Sairam MR 2001 Hormone-induced receptor gene splicing: enhanced expression of the growth factor type I folliclestimulating hormone receptor motif in the developing mouse ovary as a new paradigm in growth regulation. Endocrinology 142 381-389. (doi:10.1210/endo.142.1.7886)

Bas F, Pescovitz OH \& Steinmetz R 2009 No activating mutations of FSH receptor in four children with ovarian juvenile granulose cell tumors and the association of these tumors with central precocious puberty. Journal of Pediatric and Adolescent Gynecology 22 173-179. (doi:10. 1016/j.jpag.2008.10.003)

Beau I, Touraine P, Meduri G, Gougeon A, Desroches A, Matuchansky C, Milgrom E, Kuttenn F \& Misrahi M 1998 A novel phenotype related to partial loss of function mutations of the follicle stimulating hormone receptor. Journal of Clinical Investigation 102 1352-1359. (doi:10.1172/ JCI3795)

Bhartiya D 2012 The continued presence of stem cells and oogonia in the adult mammalian ovary. Human Reproduction 27 938. (doi:10.1093/ humrep/der423)

Bhartiya D, Kasiviswanathan S, Unni SK, Pethe P, Dhabalia JV, Patwardhan S \& Tongaonkar HB 2010 Newer insights into premeiotic development of germ cells in adult human testis using Oct-4 as a stem cell marker. Journal of Histochemistry and Cytochemistry 58 1093-1106. (doi:10.1369/jhc.2010.956870)

Bhartiya D, Sriraman K, Gunjal P \& Modak H 2012 Gonadotropin treatment augments postnatal oogenesis and primordial follicle assembly in adult mouse ovaries? Journal of Ovarian Research 5 32. (doi:10.1186/ 1757-2215-5-32)

Bhartiya D, Sriraman K, Parte S \& Patel H 2013a Ovarian stem cells: absence of evidence is not evidence of absence. Journal of Ovarian Research 6 65. (doi:10.1186/1757-2215-6-65)

Bhartiya D, Unni S, Parte S \& Anand S 2013b Very small embryonic-like stem: implications in reproductive biology. BioMed Research International 2013 682326. (doi:10.1155/2013/682326)

Bhartiya D, Sriraman K, Bhutda S, Mundekar AS, Mulla S \& Modak H 2013 C Neonatal exposure to estrogen affects very small ES-like stem cells (VSELs) leading to various pathologies in adults including cancer. Journal of Cancer Stem Cell Research 1 e1003. (doi:10.14343/JCSCR. 2013.1e1003)

Blaakaer J, Baeksted M, Micic S, Albrectsen P, Rygaard J \& Bock J 1995 Gonadotropin releasing hormone agonist suppression of ovarian tumorigenesis in mice of the $\mathrm{W} \times \mathrm{W} v$ genotype. Biology of Reproduction 53 775-779. (doi:10.1095/biolreprod53.4.775)

Bose CK 2005 Role of nerve growth factor, follicle stimulating hormone receptor and epithelial ovarian cancer. Reproductive Biomedicine Online 11 194-197. (doi:10.1016/S1472-6483(10)60958-3)

Bose CK 2008 Follicle stimulating hormone receptor in ovarian surface epithelium and epithelial ovarian cancer. Oncology Research 17 231-238. (doi:10.3727/096504008786111383)

Bukovsky A 2011 How can female germline stem cells contribute to the physiological neo-oogenesis in mammals and why menopause occurs? Microscopy and Microanalysis 17 498-505. (doi:10.1017/ S143192761000036X)

Burdett JE, Kurley SJ, Kilen SM, Mayo KE \& Woodruff TK 2006 Gonadotropin-induced superovulation drives ovarian surface epithelia proliferation in CD1 mice. Endocrinology 147 2338-2345. (doi:10. 1210/en.2005-1629)

Chakkalakal JV, Jones KM, Basson MA \& Brack AS 2012 The aged niche disrupts muscle stem cell quiescence. Nature 490 355-360. (doi:10.1038/nature11438)

Chen X, Aravindakshan J, Yang Y \& Sairam MR 2007 Early alterations in OSE and induction of ovarian epithelial tumors triggered by loss of FSHR. Neoplasia 9 521-531. (doi:10.1593/neo.07238)

de la Chesnaye E, Canto P, Ulloa-Aguirre A \& Méndez JP 2001 No evidence of mutations in the follicle-stimulating hormone receptor gene in Mexican women with 46,XX pure gonadal dysgenesis. American Journal of Medical Genetics 98 125-128. (doi:10.1002/10968628(20010115)98:2 < 125::AID-AJMG1020>3.0.CO;2-I)

Choi KC, Kang SK, Tai CJ, Auersperg N \& Leung PC 2002 Folliclestimulating hormone activates mitogen-activated protein kinase in preneoplastic and neoplastic ovarian surface epithelial cells. Journal of Clinical Endocrinology and Metabolism 87 2245-2253. (doi:10.1210/ jcem.87.5.8506)
Choi JH, Choi KC, Auersperg N \& Leung PC 2004 Overexpression of follicle stimulating hormone receptor activates oncogenic pathways in preneoplastic ovarian surface epithelial cells. Journal of Clinical Endocrinology and Metabolism 89 5508-5516. (doi:10.1210/jc.2004-0044)

Choi JH, Choi KC, Auersperg N \& Leung PC 2005 Gonadotropins upregulate the epidermal growth factor receptor through activation of mitogen-activated protein kinases and phosphatidyl-inositol-3-kinase I human ovarian surface epithelial cells. Endocrine-Related Cancer 12 407-421. (doi:10.1677/erc.1.00896)

Conway GS, Conway E, Walker C, Hoppner W, Gromoll J \& Simoni M 1999 Mutation screening and isoform prevalence of the follicle stimulating hormone receptor gene in women with premature ovarian failure, resistant ovary syndrome and polycystic ovary syndrome. Clinical Endocrinology 51 97-99. (doi:10.1046/j.1365-2265.1999.00745.x)

Danilovich N, Roy I \& Sairam MR 2001 Ovarian pathology and high incidence of sex cord tumors in follitropin receptor knockout (FORKO) mice. Endocrinology 142 3673-3684. (doi:10.1210/endo.142. 8.8320)

Davies BR, Finnigan DS, Smith SK \& Ponder BA 1999 Administration of gonadotropins stimulates proliferation of normal mouse ovarian surface epithelium. Gynecological Endocrinology 13 75-81. (doi:10.3109/ 09513599909167536)

Dierich A, Sairam MR, Monaco L, Fimia GM, Gansmuller A, LeMeur M \& Sassone-Corsi P 1998 Impairing FSH signalling in vivo: targeted disruption of FSHR leads to aberrant gametogenesis and hormonal imbalance. PNAS 95 13612-13617. (doi:10.1073/pnas.95.23.13612)

Doherty E, Pakarinen P, Tiitinen A, Kiilavuori A, Huhtaniemi I, Forrest S \& Aittomäki K 2002 A novel mutation in the FSH receptor inhibiting signal transduction and causing primary ovarian failure. Journal of Clinical Endocrinology and Metabolism 87 1151-1155. (doi:10.1210/ jcem.87.3.8319)

Fathalla MF 1971 Incessant ovulation - a factor in ovarian neoplasia? Lancet 2 163. (doi:10.1016/S0140-6736(71)92335-X)

Flesken-Nikitin A, Hwang Cl, Cheng CY, Michurina TV, Enikolopov G \& Nikitin AY 2013 Ovarian surface epithelium at the junction area contains a cancer-prone stem cell niche. Nature 495 241-245. (doi:10.1038/ nature11979)

Gaytan M, Sanchez MA, Morales C, Bellido C, Millan Y, Martín de Las Mulas J, Sánchez-Criado JE \& Gaytán F 2005 Cyclic changes of the ovarian surface epithelium in the rat. Reproduction 129 311-321. (doi:10.1530/rep.1.00401)

Hilliard TS, Modi DA \& Burdette JE 2013 Gonadotropinsactivate oncogenic pathways to enhance proliferation in normal mouse ovarian surface epithelium. International Journal of Molecular Sciences 14 4762-4782. (doi:10.3390/ijms14034762)

Huhtaniemi IT \& Themmen AP 2005 Mutations in human gonadotropin and gonadotropin-receptor genes. Endocrine 26 207-217. (doi:10.1385/ ENDO:26:3:207)

Ji Q, Liu PI, Chen PK \& Aoyama C 2004 Follicle stimulating hormoneinduced growth promotion and gene expression profiles on ovarian surface epithelial cells. International Journal of Cancer 112 803-814. (doi:10.1002/ijc.20478)

Jiang M, Aittomaki K, Nilsson C, Pakarinen P, litia A, Torresani T, Simonsen H, Goh V, Pettersson K, de la Chapelle A et al. 1998 The frequency of an inactivating point mutation $(566 \mathrm{C} \rightarrow \mathrm{T}$ ) of the human follicle stimulating hormone receptor gene in four populations using allele-specific hybridization and time-resolved fluorometry. Journal of Clinical Endocrinology and Metabolism 83 4338-4343. (doi:10.1210/ jcem.83.12.5306)

Johnson J, Canning J, Kaneko T, Pru JK \& Tilly JL 2004 Germline stem cells and follicular renewal in the postnatal mammalian ovary. Nature $\mathbf{4 2 8}$ 145-150. (doi:10.1038/nature02316)

Jones TD, Ulbright TM, Eble JN \& Cheng L 2004 OCT4: a sensitive and specific biomarker for intratubular germ cell neoplasia of the testis. Clinical Cancer Research 10 8544-8547. (doi:10.1158/1078-0432.CCR-04-0688)

Karst AM, Levanon K \& Drapkin R 2011 Modeling high-grade serous ovarian carcinogenesis from the fallopian tube. PNAS $\mathbf{1 0 8} 7547-7552$. (doi:10.1073/pnas.1017300108)

Khan H, Yarney TA \& Sairam MR 1993 Cloning of alternatively spliced mRNA transcripts coding for variants of ovine testicular follitropin receptor lacking the G protein coupling domains. Biochemical and Biophysical Research Communications 190 888-894. (doi:10.1006/bbrc.1993.1132) 
Kuechler A, Hauffa BP, Koninger A, Kleinau G, Albrecht B, Horsthemke B \& Gromoll J 2010 An unbalanced translocation unmasks a recessive mutation in the follicle-stimulating hormone receptor (FSHR) gene and causes FSH resistance. European Journal of Human Genetics 18 656-661. (doi:10.1038/ejhg.2009.244)

Layman LC, Amde S, Cohen DP, Jin M \& Xie J 1998 The Finnish follicle stimulating hormone receptor (FSHR) gene mutation in women with $46, X X$ ovarian failure is rare in the United States. Fertility and Sterility 69 300-302. (doi:10.1016/S0015-0282(97)00480-9)

Li Y, Ganta S, Cheng C, Craig R, Ganta RR \& Freeman LC 2007 FSH stimulates ovarian cancer cell growth by action on growth factor variant receptor. Molecular and Cellular Endocrinology 267 26-37. (doi:10.1016/j.mce.2006.11.010)

Ma W, Ma J, Xu J, Qiao C, Branscum A, Cardenas A, Baron AT, Schwartz P, Maihle NJ \& Huang Y 2013 Lin28 regulates BMP4 and functions with Oct4 to affect ovarian tumor microenvironment. Cell Cycle 12 88-97. (doi:10.4161/cc.23028)

Massasa E, Costa XS \& Taylor HS 2010 Failure of the stem cell niche rather than loss of oocyte stem cells in the aging ovary. Aging 2 1-2.

Meduri G, Charnaux N, Driancourt MA, Combettes L, Granet P, Vannier B, Loosfelt H \& Milgrom E 2002 Follicle-stimulating hormone receptors in oocytes. Journal of Clinical Endocrinology and Metabolism 87 2266-2276. (doi:10.1210/jcem.87.5.8502)

Meduri G, Touraine P, Beau I, Lahuna O, Desroches A, Vacher-Lavenu MC, Kuttenn F \& Misrahi M 2003 Delayed puberty and primary amenorrhea associated with a novel mutation of the human follicle-stimulating hormone receptor: clinical, histological, and molecular studies. Journal of Clinical Endocrinology and Metabolism 88 3491-3498. (doi:10.1210/jc.2003-030217)

Mertens-Walker I, Bolitho C, Baxter RC \& Marsh DJ 2010 Gonadotropininduced ovarian cancer cell migration and proliferation require extracellular signal-regulated kinase $1 / 2$ activation regulated by calcium and protein kinase C $\delta$. Endocrine-Related Cancer 8 335-349. (doi:10. 1677/ERC-09-0152)

Mertens-Walker I, Baxter RC \& Marsh DJ 2012 Gonadotropin signalling in epithelial ovarian cancer. Cancer Letters 324 152-159. (doi:10.1016/j. canlet.2012.05.017)

Murphy ED \& Beamer WG 1973 Plasma gonadotropin levels during early stages of ovarian tumorigenesis in mice of the $\mathrm{W}^{\mathrm{x}} / \mathrm{W}^{\mathrm{v}}$ genotype. Cancer Research 33 721-723. (doi:10.1.1.325.866)

Niikura Y, Niikura T \& Tilly JL 2009 Aged mouse ovaries possess rare premeiotic germ cells that can generate oocytes following transplantation into a young host environment. Aging 1 971-978. (doi:10. 1016/j.diff.2010.01.001)

Oatley JM \& Brinster RL 2012 The germline stem cell niche unit in mammalian testes. Physiological Reviews 92 577-595. (doi:10.1152/ physrev.00025.2011)

Parrott JA, Doraiswamy V, Kim G, Mosher R \& Skinner MK 2001 Expression and actions of both the follicle stimulating hormone receptor and the luteinizing hormone receptor in normal ovarian surface epithelium and ovarian cancer. Molecular and Cellular Endocrinology 172 213-222. (doi:10.1016/S0303-7207(00)00340-3)

Parte S, Bhartiya D, Telang J, Daithankar V, Salvi V, Zaveri K \& Hinduja I 2011 Detection, characterization, and spontaneous differentiation in vitro of very small embryonic-like putative stem cells in adult mammalian ovary. Stem Cells and Development 20 1451-1464. (doi:10. 1089/scd.2010.0461)

Parte S, Bhartiya D, Manjramkar DD, Chauhan A \& Joshi A 2013 Stimulation of ovarian stem cells by follicle stimulating hormone and basic fibroblast growth factor during cortical tissue culture. Journal of Ovarian Research 6 20. (doi:10.1186/1757-2215-6-20)

Parte S, Bhartiya D, Patel H, Daithankar V, Chauhan A, Zaveri K \& Hinduja I 2014 Dynamics associated with spontaneous differentiation of ovarian stem cells in vitro. Journal of Ovarian Research 725 (doi:10.1186/1757-2215-7-25)

Patel H, Bhartiya D, Parte S, Gunjal P \& Bhatt M 2013 FSH stimulates ovarian stem cells via alternately spliced receptor variant (FSH-R3) to induce postnatal oogenesis. Journal of Ovarian Research 652. (doi:10.1186/1757-2215-6-52)

Peng S, Maihle NJ \& Huang Y 2010 Pluripotency factors Lin28 and Oct4 identify a sub-population of stem cell-like cells in ovarian cancer. Oncogene 29 2153-2159. (doi:10.1038/onc.2009.500)
Qin Y, Zhao H, Xu J, Shi Y, Li Z, Qiao J, Liu J, Qin C, Ren C, Li J et al. 2012 Association of 8q22.3 locus in Chinese Han with idiopathic premature ovarian failure (POF). Human Molecular Genetics 21 430-436. (doi:10.1093/hmg/ddr462)

Radu A, Pichon C, Camparo P, Antoine M, Allory Y, Couvelard A, Fromont G, Vu Hai MT \& Ghinea N 2010 Expression of folliclestimulating hormone receptor in tumor blood vessels. New England Journal of Medicine 363 1621-1630. (doi:10.1056/NEJMoa1001283)

Ratajczak MZ, Shin DM, Liu R, Marlicz W, Tarnowski M, Ratajczak J \& Kucia M 2010 Epiblast/germ line hypothesis of cancer development revisited: lesson from the presence of Oct- $4+$ cells in adult tissues. Stem Cell Reviews 6 307-316. (doi:10.1007/s12015-010-9143-4)

Ratajczak J, Wysoczynski M, Zuba-Surma E, Wan W, Kucia M, Yoder MC \& Ratajczak MZ 2011 Adult murine bone marrow-derived very small embryonic-like stem cells differentiate into the hematopoietic lineage after coculture over OP9 stromal cells. Experimental Hematology 39 225-237. (doi:10.1016/j.exphem.2010.10.007)

Ratajczak MZ, Zuba-Surma E, Wojakowski W, Suszynska M, Mierzejewska K, Liu R, Ratajczak J, Shin DM \& Kucia M 2014 Very small embryonic-like stem cells (VSELs) represent a real challenge in stem cell biology: recent pros and cons in the midst of a lively debate. Leukemia 28 473-484. (doi:10.1038/leu.2013.255)

Renner M, Goeppert B, Siraj MA, Radu A, Penzel R, Wardelmann E, Lehner B, Ulrich A, Stenzinger A, Warth A et al. 2013 Folliclestimulating hormone receptor expression in soft tissue sarcomas. Histopathology 63 29-35. (doi:10.1111/his.12135)

Sairam MR \& Babu PS 2007 The tale of follitropin receptor diversity: a recipe for fine tuning gonadal responses? Molecular and Cellular Endocrinology 260-262 163-171. (doi:10.1016/j.mce.205.11.052)

Sairam MR \& Subbarayan VS 1997 Characterization of the 5' flanking region and potential control elements of the ovine follitropin receptor gene. Molecular Reproduction and Development 48 480-487. (doi:10. 1002/(SICl)1098-2795(199712)48:4 <480::AID-MRD8 > 3.0.CO;2-M)

Sairam MR, Jiang LG, Yarney TA \& Khan H 1997 Alternative splicing converts the G-protein coupled follitropin receptor gene into a growth factor type I receptor: implications for pleiotropic actions of the hormone. Molecular Reproduction and Development 48 471-479. (doi:10.1002/(SICl)1098-2795(199712)48:4<471::AID-MRD7> 3.0 $\mathrm{CO} ; 2-\mathrm{N})$

Samardzija C, Quinn M, Findlay JK \& Ahmed N 2012 Attributes of Oct4 in stem cell biology: perspectives on cancer stem cells of the ovary. Journal of Ovarian Research 5 37. (doi:10.1186/1757-2215-5-37)

Schiffenbauer YS, Abramovitch R, Meir G, Nevo N, Holzinger M, Itin A, Keshet E \& Neeman M 1997 Loss of ovarian function promotes angiogenesis in human ovarian carcinoma. PNAS 94 13203-13208. (doi:10.1073/pnas.94.24.13203)

Schildkraut JM, Cooper GS, Halabi S, Calingaert B, Hartge P \& Whittemore AS 2001 Age at natural menopause and the risk of epithelial ovarian cancer. Obstetrics and Gynecology 98 85-90. (doi:10.1016/ S0029-7844(01)01388-6)

Siegel ET, Kim HG, Nishimoto HK \& Layman LC 2013 The molecular basis of impaired follicle-stimulating hormone action: evidence from human mutations and mouse models. Reproductive Sciences 20 211-233. (doi:10.1177/1933719112461184)

Simpson JL 2008 Genetic and phenotypic heterogeneity in ovarian failure: overview of selected candidate genes. Annals of the New York Academy of Sciences 1135 146-154. (doi:10.1196/annals.1429.019)

Simpson JL 2013 Genetics of premature ovarian failure. In Transforming Reproductive Medicine Worldwide Proceedings of 69th Annual Meeting of the American Society for Reproductive Medicine, Boston, USA, Eds BC Tarlatzis \& SE Bulun. ASRM, Alabama: USA.

Singavarapu R, Buchinsky N, Cheon DJ \& Orsulic S 2010 Whole ovary immunohistochemistry for monitoring cell proliferation and ovulatory wound repair in the mouse. Reproductive Biology and Endocrinology $\mathbf{8}$ 98. (doi:10.1186/1477-7827-8-98)

Siraj A, Desestret V, Antoine $M$, Fromont $G$, Huerre $M$, Sanson $M$, Camparo P, Pichon C, Planeix F, Gonin J et al. 2013 Expression of follicle-stimulating hormone receptor by the vascular endothelium in tumor metastases. BMC Cancer 13 246. (doi:10.1186/1471-2407$13-246)$ 
Smith ER \& Xu XX 2008 Ovarian ageing, follicle depletion, and cancer: a hypothesis for the aetiology of epithelialn ovarian cancer involving follicle depletion. Lancet Oncology 9 1108-1111. (doi:10.1016/S14702045(08)70281-X)

Stadel BV 1975 Letter: the etiology and prevention of ovarian cancer. American Journal of Obstetrics and Gynecology 123 772-774. (doi:10.1210/endo.142.8.8320?ck=nck)

Stewart SL, Querec TD, Gruver BN, O'Hare B, Babb JS \& Patriotis C 2004 Gonadotropin and steroid hormones stimulate proliferation of the rat ovarian surface epithelium. Journal of Cellular Physiology 198 119-124. (doi:10.1002/jcp.10401)

Sullivan RR, Faris BR, Eborn D, Grieger DM, Cino-Ozuna AG \& Rozell TG 2013 Follicular expression of follicle stimulating hormone receptor variants in the ewe. Reproductive Biology and Endocrinology 11113. (doi:10.1186/1477-7827-11-113)

Sundblad V, Chiauzzi VA, Escobar ME, Dain L \& Charreau EH 2004 Screening of $\mathrm{FSH}$ receptor gene in Argentine women with premature ovarian failure (POF). Molecular and Cellular Endocrinology 222 53-59. (doi:10.1016/j.mce.2004.05.002)

Syed V, Ulinski G, Mok SC, Yiu GK \& Ho SM 2001 Expression of gonadotropin receptor and growth responses to key reproductive hormones in normal and malignant human ovarian surface epithelial cells. Cancer Researchf 61 6768-6776.

Szotek PP, Chang HL, Brennand K, Fujino A, Pieretti-Vanmarcke R, Lo Celso C, Dombkowski D, Preffer F, Cohen KS, Teixeira J et al. 2008 Normal ovarian surface epithelial label-retaining cells exhibit stem/progenitor cell characteristics. PNAS 105 12469-12473. (doi:10.1073/pnas. 0805012105)

Takakura K, Takebayashi K, Wang HQ, Kimura F, Kasahara K \& Noda Y 2001 Follicle-stimulating hormone receptor gene mutations are rare in Japanese women with premature ovarian failure and polycystic ovary syndrome. Fertility and Sterility 75 207-209. (doi:10.1016/S0015-0282(00)01673-3)

Tan OL \& Fleming JS 2004 Proliferating cell nuclear antigen immunoreactivity in the ovarian surface epithelium of mice of varying ages and total lifetime ovulation number following ovulation. Biology of Reproduction 71 1501-1507. (doi:10.1095/biolreprod.104.030460)

Themmen AP 2005 An update of the pathophysiology of human gonadotrophin subunit and receptor gene mutations and polymorphisms. Reproduction 130 263-274. (doi:10.1530/rep.1.00663)

Themmen APN \& Huhtaniemi I 2000 Mutations of gonadotropins and gonadotropin receptors: elucidating the physiology and pathophysiology of pituitary-gonadal function. Endocrine Reviews 21 551-583. (doi:10.1210/edrv.21.5.0409)

Tilly JL \& Telfer EE 2009 Purification of germline stem cells from adult mammalian ovaries: a step closer towards control of the female biological clock? Molecular Human Reproduction 15 393-398. (doi:10.1093/molehr/gap036)

Touraine P, Beau I, Gougeon A, Meduri G, Desroches A, Pichard C, Detoeuf M, Paniel B, Prieur M, Zorn JR et al. 1999 New natural inactivating mutations of the follicle-stimulating hormone receptor: correlation between receptor function and phenotype. Molecular Endocrinology 13 1844-1854. (doi:10.1210/mend.13.11.0370)

Touyz RM, Jiang L \& Sairam MR 2000 Follicle-stimulating hormone mediated calcium signaling by the alternatively spliced growth factor type I receptor. Biology of Reproduction 62 1067-1074. (doi:10.1095/ biolreprod62.4.1067)

Vilodre LC, Kohek MB \& Spritzer PM 2008 Screening of follicle-stimulating hormone receptor gene in women with premature ovarian failure in southern Brazil and associations with phenotype. Journal of Endocrinological Investigation 31 552-557. (doi:10.1007/BF03346407)

Virant-Klun I \& Skutella T 2010 Stem cells in aged mammalian ovaries. Aging 2 3-6. (doi:10.1186/1757-2215-4-13)

Virant-Klun I, Skutella T, Hren M, Gruden K, Cvjeticanin B, Vogler A \& Sinkovec J 2013 Isolation of small SSEA-4-positive putativestem cellsfrom the ovarian surface epithelium of adult human ovaries by two different methods. BioMed Research International 2013690415. (doi:10.1155/2013/690415)
Vu Hai MT, Lescop P, Loosfelt H \& Ghinea N 2004 Receptor-mediated transcytosis of follicle stimulating hormone through the rat testicular microvasculature. Biology of the Cell 96 133-144. (doi:10.1016/ j.biolcel.2003.11.008)

Wang J, Lin L, Prakash V, Schwartz PE, Lauchlan SC \& Zheng W 2003 Quantitative analysis of follicle-stimulating hormone receptor in ovarian epithelial tumors: a novel approach to explain the field effect of ovarian cancer development in secondary mullerian systems. International Journal of Cancer 103 328-334. (doi:10.1002/ijc.10848)

Woad KJ, Prendergast D, Winship IM \& Shelling AN 2013 FSH receptor gene variants are rarely associated with premature ovarian failure. Reproductive Biomedicine Online 26 396-399. (doi:10.1016/j.rbmo. 2013.01.004)

Woods DC \& Tilly JL 2013 Isolation, characterization and propagation of mitotically active germ cells from adult mouse and human ovaries. Nature Protocols 8 966-988. (doi:10.1038/nprot.2013.047)

Woods DC, White YA \& Tilly JL 2013 Purification of oogonial stem cells from adult mouse and human ovaries: an assessment of the literature and a view toward the future. Reproductive Sciences 20 7-15. (doi:10.1177/ 1933719112462632)

Wright JW, Toth-Fejel S, Stouffer RL \& Rodland KD 2002 Proliferation of rhesus ovarian surface epithelial cells in culture: lack of mitogenic response to steroid or gonadotropic hormones. Endocrinology 143 2198-2207. (doi:10.1210/endo.143.6.8848)

Xu J \& Gridley T 2013 Notch2 is required in somatic cells for breakdown of ovarian germ-cell nests and formation of primordial follicles. BMC Biology 11 13. (doi:10.1186/1741-7007-11-13)

Yarney TA, Sairam MR, Khan H, Ravindranath N, Payne S \& Seidah NG 1993 Molecular cloning and expression of the ovine testicular follicle stimulating hormone receptor. Molecular and Cellular Endocrinology 93 219-226. (doi:10.1016/0303-7207(93)90127-6)

Yarney TA, Jiang L, Khan H, MacDonald EA, Laird DW \& Sairam MR 1997a Molecular cloning, structure, and expression of a testicular follitropin receptor with selective alteration in the carboxy terminus that affects signalling function. Molecular Reproduction and Development 48 458-470. (doi:10.1002/(SICI)1098-2795(199712)48:4<458::AID-MRD $6>3.0 . \mathrm{CO} ; 2-\mathrm{P})$

Yarney TA, Fahmy MH, Sairam MR, Khan H \& Macdonald EA 1997b Ontogeny of FSH receptor messenger ribonucleic acid transcripts in relation to $\mathrm{FSH}$ secretion and testicular function in sheep. Journal of Molecular Endocrinology 18 113-125. (doi:10.1677/jme.0. 0180113)

Zhang XY, Chen J, Zheng YF, Gao XL, Kang Y, Liu JC, Cheng MJ, Sun H \& Xu CJ 2009 Follicle-stimulating hormone peptide can facilitate paclitaxelnanoparticlesto target ovarian carcinoma in vivo. Cancer Research 69 6506-6514. (doi:10.1158/0008-5472.CAN-08-4721)

Zhang Z, Zhu Y, Lai Y, Wu X, Feng Z, Yu Y, Bast RC Jr, Wan X, Xi X \& Feng Y 2013 Follicle-stimulating hormone inhibits apoptosis in ovarian cancer cells by regulating the OCT4 stem cell signaling pathway. International Journal of Oncology 43 1194-1204. (doi:10.3892/ijo.2013.2054)

Zheng W, Magid MS, Kramer EE \& Chen YT 1996 Follicle-stimulating hormone receptor is expressed in human ovarian surface epithelium and fallopian tube. American Journal of Pathology 148 47-53. (doi:10.1006/ gyno.1999.5628)

Zheng W, Lu JJ, Luo F, Zheng Y, Feng YJ, Felix JC, Lauchlan SC \& Pike MC 2000 Ovarian epithelial tumor growth promotion by follicle-stimulating hormone and inhibition of the effect by luteinizing hormone. Gynecologic Oncology 76 80-88. (doi:10.1006/gyno.1999.5628)

Received 23 April 2014

First decision 16 June 2014

Revised manuscript received 25 September 2014

Accepted 30 September 2014 